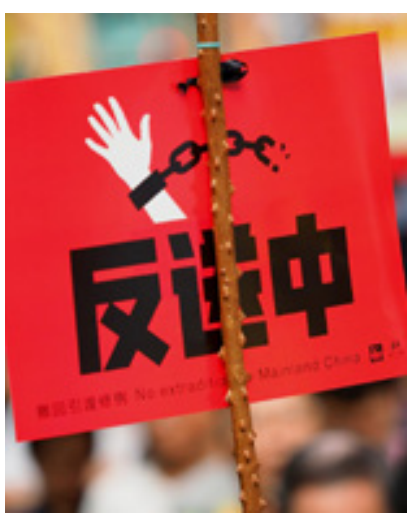

'Opposing Extradition to China'. PC: Etan Liam

\section{Compelled Reticence \\ Overseas Mainland Chinese amid Mass Protests in Hong Kong}

Daphne ZHAO

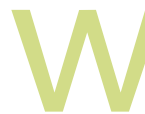

hen the mass protests against the extradition bill first broke out in Hong Kong in late March, I was not particularly surprised by this new wave of mobilisation. After all, having lived in Hong Kong for a few years I had already witnessed numerous protests that had drawn global attention to the Asian financial centre, including the Umbrella Movement of late 2014. Yet, when I heard that as many as two million people in Hong Kong-more than one quarter of its current population-took to the streets on 16 June, one day after the Chief Executive of Hong Kong indefinitely suspended, but stopped short of withdrawing, the extradition bill, I had to admit that I had underestimated the movement. With the mass protests in Hong Kong now entering their 14th consecutive week, I am both shocked and concerned about the scale and intensity of this ongoing mobilisation, which has drawn protesters from a variety of social-economic backgrounds and propelled tensions between local citizens and the police to new highs.

Equally unsettling for me is the intensifying Chinese nationalism in both mainland China and Hong Kong, as well as its swift spread to foreign countries, including Australia where I currently live after concluding my studies at a local university. This is not only putting immense peer pressure on overseas mainland Chinese to fully conform to such nationalist sentiment, but also has ramifications for those who deviate from it, let alone go against it. This situation, together with the covert, yet widespread, surveillance of mainland Chinese overseas and the lack of adequate protection for those expressing critical views, has engendered an alarming tendency among this group of people to engage in self-censorship when expressing themselves publicly. An increasing number of mainland Chinese overseas simply opt for (or are pressured into) reticence, and keep their thoughts to themselves or, at best, exchange them only with their inner circle of friends. They seldom, if at all, dare to discuss their opinions among a large group of people, let alone openly on social media platforms or in the press. 
Since the mass

protests in Hong Kong

gained momentum

in mid-June, Chinese

nationalism has been

intensifying swiftly both

in state media and on

social media platforms.
Since the mass protests in Hong Kong gained momentum in mid-June, Chinese nationalism has been intensifying swiftly both in state media and on social media platforms. On WeChat, for example, the ever-rising nationalist sentiment has taken a wide range of forms: from sharing official media posts about what has been happening in Hong Kong and circulating images or videos of the People's Armed Police conducting drills in Shenzhen, to expressing staunch support for the Hong Kong police and even calling for blacklisting or unfriending anyone who has yet to demonstrate his or her 'patriotism'.

While I am astounded by how quickly Chinese nationalism has intensified on Chinese social media platforms, I am even more appalled at the intensity of the nationalist sentiment displayed by mainland Chinese in Hong Kong compared to their counterparts in mainland China. While most of my WeChat contacts in mainland China simply share posts or articles that advocate the official Party stance without further comments from themselves, quite a few of my WeChat contacts who came from mainland China but now reside in Hong Kong have not only circulated these posts or articles but also accompanied them with strong words of condemnation for ungrateful Hong Kong protesters and intentional foreign interference in China's domestic affairs. In a repost of an article entitled 'I Support Hong Kong Police; You Can Beat Me Up Now, one of my WeChat contacts, who has been working for an insurance company in Hong Kong for several years, first lamented that reporting on the mass protests by Western media had been biased towards protesters, portraying them as peaceful demonstrators in spite of their violent behaviour and malicious intent. He then vowed to go on more business trips to inform his clients abroad of the real situations in the city and warn them against the misinformation provided by their own press.

Hiding behind this ever-rising Chinese nationalism on social media platforms is a much less discernible phenomenon. Some mainland Chinese who have been living in Hong Kong for several years and who used to be quite active in sharing their views online have become less active, if not completely silent. Having noticed this phenomenon, I reached out to a few of them. Starting with everyday topics, such as new movies and recent sports games, my conversations with all of them went on well until I raised the question of the reasons for their radio silence. Two of them stopped responding to me, probably feeling suspicious of my intentions in asking them such a question; the others simply replied that 'there was nothing special', which triggered my follow-up question of how everything had been going in Hong Kong. At that point, they all ignored my messages. The ensuing silence was disappointing but not surprising 


Despite being
thousands of
kilometres away from
China, Australia has
not been immune
to this intensifying
Chinese nationalism.
Since early July, social
media platforms-
both Chinese and
Western-have turned
into fiercely-contested
battlegrounds.

Despite being

thousands of

kilometres away from

China, Australia has

not been immune

to this intensifying

Since early July, social

media platforms-

both Chinese and

into fiercely-contested

battlegrounds. to me. Above all, it is no secret that privacy has always been elusive on WeChat, especially during such politically sensitive times. While I was still disenchanted by the ending of my unfinished conversations on the app, my local friends in Hong Kong told me that on WhatsApp certain companies there had urged their employees to act 'responsibly' towards the ongoing demonstrations and warned that suspension letters or even dismissal letters would be issued to recalcitrant employees. Probably not coincidentally, many of my WeChat contacts were working for such companies.

Despite being thousands of kilometres away from China, Australia has not been immune to this intensifying Chinese nationalism. Since early July, social media platforms-both Chinese and Western-have turned into fiercely-contested battlegrounds. Apart from ardently promoting the official Party stance on the mass protests, online Chinese nationalist behaviour in Australia and other foreign countries also entails insulting, harassing, and doxing people-mainly overseas mainland Chinese-with viewpoints sympathetic to the Hong Kong protestors, as well as rallying the Chinese community to undertake 'patriotic' actions. Epitomising this are pro-Beijing demonstrations, which have been staged at numerous locations since late July, from university campuses to city centres, where demonstrators have shown their ardour in many different forms, ranging from chanting nationalist slogans to verbally or even physically attacking pro-Hong Kong counter-demonstrators.

Overshadowed by this spread of aggressive Chinese nationalism to Australia is the heightened wariness and restraint shown by a growing number of mainland Chinese in the country. During a casual gathering with some friends a few weeks ago, I was introduced to a girl from Hong Kong who had come to Australia for study earlier this year. After I introduced myself, she posed a question that caught me off guard: 'What do you think of the ongoing protests in Hong Kong?' As I was about to respond, I realised that several mainland Chinese who were sitting at a table right next to ours had suddenly stopped chatting and turned their attention to our table. Having no idea about who these people were, I changed my mind: rather than saying what I intended to say, I decided to dodge her question. Deep frustration immediately appeared on the face of the girl, from which I could clearly tell that she was convinced that I was just another mainland Chinese who had been indoctrinated and who would never be capable of critical thinking or have 
independent opinions. I did not have further interactions with her until we said goodbye to each other at the end of the gettogether.

Some days later, I still found myself haunted by the girl's frustrated expression and the uncomfortable silence between us throughout the meeting. I therefore decided to ring up a trustworthy friend who also came from mainland China and had spent several years living in Hong Kong before relocating to Australia a few years ago. Having listened to me recount the experience and vent my disappointment in myself for not being courageous enough to express my opinion, he remained silent for a while and then said: 'I was actually involved in a similar situation a couple of weeks ago and responded in the same way as you did. I also know many other mainland Chinese in Australia who avoid voicing their opinions in such circumstances. For us, it is not really about personal bravery: after all, we still want to see our family in China, don't we?'

As the intensifying Chinese nationalism in mainland China and Hong Kong spreads abroad and sparks tensions in Australia and other countries that have a sizeable presence of ethnic Chinese, the widely-reported scenes of overseas mainland Chinese staging pro-Beijing demonstrations or targetting proHong Kong protestors have made it tempting to jump to the conclusion that attitudes towards the ongoing mass protests in Hong Kong have become a fault line in the overseas Chinese community. According to this narrative, overseas mainland Chinese belong to the pro-Beijing camp and the other ethnic Chinese groups fall into the pro-Hong Kong camp. Some observers even go as far as to imply that the vast majority of mainland Chinese are brainwashed and condemn them (us), especially those overseas, for shamefully coming to the defence of Beijing.

I would not deny that some overseas mainland Chinese are prone to blind patriotism, but the ill-founded generalisations that depict all overseas mainland Chinese as mindlessly siding with Beijing render me as much saddened as irritated, not least because insufficient attention has been paid to the reasons behind the phenomenon of overseas mainland Chinese toeing the official Party line. The swift spread of Chinese nationalism into Australia, and the even more aggressive forms that such nationalist sentiment may take, make it plain that overseas mainland Chinese who hold different viewpoints from the official Party stance are as likely to face serious pressure to 
follow the official Party line as their counterparts in mainland China and Hong Kong, despite the fact that they live in a Western democracy.

Exacerbating the pressure is the covert yet pervasive surveillance of overseas mainland Chinese exerted by the Chinese government, whose arsenal spans from individual informants to state-sponsored spying networks. The very presence of such surveillance has diluted the freedom that mainland Chinese can enjoy while living overseas in democratic countries. This diluted freedom not only restrains overseas mainland Chinese who do not want to uncritically side with Beijing from expressing their opinions, but also prevents them from informing people in China of accounts of the mass protests in Hong Kong that differ from the official version. They also cannot engage in open and constructive conversations with mainland Chinese who ardently defend Beijing to help find common ground to defuse the tensions.

Granted, there are a handful of overseas mainland Chinese who did choose to speak up for Hong Kong against enormous peer pressure and omnipresent surveillance, but the consequences they suffered seem to have ended up reinforcing the growing reticence among overseas mainland Chinese. The deterrent effects of being doxed, insulted, or intimidated would probably not be so strong were such acute consequences contained only to the people who chose to make their voices heard, but the fact that all the ramifications may well extend to family members and that they could be prohibited from even seeing their family again have rendered the deterrence all the more effective.

The diffidence among overseas mainland Chinese who do not want to uncritically side with Beijing is indeed disheartening and alarming.
Not all overseas mainland Chinese are uncritical champions of the official Party line, but at the same time not all of them are outspoken about their standpoints. For many overseas mainland Chinese whose views differ from the official Party stance, being reticent is not so much a voluntary choice as a forced decision due to the combined effects of the immense peer pressure from mainland Chinese who ardently defend Beijing, the covert yet omnipresent state surveillance by the Chinese government of overseas Chinese, the ramifications of contradicting the official Party stance, and, above all, the lack of sufficient protection for speaking up.

The diffidence among overseas mainland Chinese who do not want to uncritically side with Beijing is indeed disheartening and alarming. On the one hand, this group of people is constrained from informing people in China about the other side of the story and from helping their peers who are prone to 
blind patriotism to think critically, although they are probably better positioned for these tasks given their access to different sources of information. On the other hand, this compelled reticence among overseas mainland Chinese might well develop into perpetual silence, as the diluted freedom that they can at best enjoy while living in democratic countries could render them so disillusioned that they would eventually give up hope of ever being able to truly speak their minds. If such disillusionment becomes widespread, this would be a coveted victory for Beijing and a resounding defeat for democracies worldwide.

The extradition bill that sparked the mass protests in Hong Kong has now been withdrawn, but the demonstrations there are still ongoing and, along with them, the compelled reticence among overseas mainland Chinese. Just as it is urgent to find an effective solution to the turmoil in Hong Kong, it is critical to resolve the uncomfortable silence in the overseas Chinese community and create a safer environment for everyone to voice their viewpoints, support and dissent alike. 